\title{
BCL-2, CDKN1A AND ATM GENE METHYLATION IN CHRONICALLY EXPOSED INDIVIDUALS
}

Blinova $E A^{1,2} \otimes$, Nikiforov $V^{1,2}$, Yanishevskaya $\mathrm{MA}^{1}$, Akleyev $A V^{1,2}$

${ }^{1}$ Urals Research Center for Radiation Medicine of the Federal Medical Biological Agency, Chelyabinsk, Russia

${ }^{2}$ Chelyabinsk State University, Chelyabinsk, Russia

\begin{abstract}
DNA methylation is the most common epigenetic modification, caused by ionizing radiation. There may be both hypermethylation, which suppresses transcription of gene promoter regions, and hypomethylation, resulting in gene activation. Both mechanisms may be involved in carcinogenesis. The study was aimed to assess methylation status of $\mathrm{CpG}$ islands in the protective system BCL-2, CDKN1A and ATM gene promoters in the peripheral blood cells of the chronically exposed individuals, living in the villages, located along the Techa River, over a long-term period. Methylation of BCL-2, CDKN1A and ATM gene promoter regions in 68 residents of the villages, located along the Techa River (Chelyabinsk region), was assessed by the real-time methylation-specific PCR. The group of exposed individuals included 54 people with accumulated dose to red bone marrow within the range of 0.09-3.51 Gy. The comparison group included 14 people, living in similar economic and social environment, with the dose to red bone marrow, accumulated during the whole life, not exceeding 70 mGy. The pilot study of exposed individuals over a long period of time after chronic low-dose radiation exposure revealed no significant changes in methylation levels of CpG islands in the CDKN1A, BCL-2, ATM gene promoter regions compared to the comparison group. None were revealed in the dose subgroups "87-994 mGy" and "over 1000 mGy".
\end{abstract}

Keywords: DNA methylation, CpG islands, long-term effects of exposure, chronic exposure, methylation-specific PCR

Funding: the study was carried out within the framework of the State assignment of Russian Federal Medical Biological Agency "Human Cell-Mediated Immunity During Realization of Chronic Radiation Exposure Late Effects" (code 27.002.20.800).

Author contribution: Blinova EA — literature analysis, experimental procedure, data processing, manuscript writing; Nikiforov VS — literature analysis, experimental procedure, manuscript writing; Yanishevskaya MA — experimental procedure, manuscript editing; Akleyev AV — general management, manuscript writing.

Compliance with ethical standards: the study was approved by the Ethics Committee of Ural Research Center for Radiation Medicine of Russian Federal Medical Biological Agency (protocol № 2 dated July 20, 2021).The informed consent was submitted by all examined individuals.

$\triangle$ Correspondence should be addressed: Evgeniya A. Blinova Vorovskogo, 68, korp. 1, Chelyabinsk, 454141; blinova@urcrm.ru

Received: 27.07.2021 Accepted: 29.08.2021 Published online: 21.09.2021

DOI: $10.47183 /$ mes.2021.028

\section{МЕТИЛИРОВАНИЕ ГЕНОВ ВCL-2, CDKN1A И АТМУ ЛИЦ, ПОДВЕРГШИХСЯ ХРОНИЧЕСКОМУ ОБЛУЧЕНИЮ}

\section{Е. А. Блинова ${ }^{1,2}$, В. С. Никифоров ${ }^{1,2}$, М. А. Янишевская ${ }^{1}$, А. В. Аклеев ${ }^{1,2}$}

1 Уральский научно-практический центр радиационной медицины Федерального медико-биологического агентства, Челябинск, Россия

2 Челябинский государственный университет, Челябинск, Россия

Метилирование ДНК является наиболее распространенной эпигенетической модификацией, вызываемой ионизирующим излучением. При этом можно наблюдать как гиперметилирование, которое подавляет транскрипцию промоторных областей генов, так и гипометилирование, приводящее к активации генов. Оба указанных механизма могут принимать участие в канцерогенезе. Целью настоящего исследования было оценить статус метилирования СрGостровков промоторов генов защитных систем BCL-2, CDKN1A и ATM в клетках периферической крови у хронически облученных жителей прибрежных сел р. Течи (Челябинская область) в отдаленные сроки. Оценку метилирования промоторных регионов генов BCL-2, CDKN1A и ATM у 68 человек, проживающих в селах, расположенных по берегам р. Течи, проводили методом метилспецифичной ПцР в реальном времени. В группу облученных лиц вошли 54 человека, у которых кумулятивные дозы красного костного мозга находились в диапазоне от 0,09 до 3,51 Гр. Группа сравнения состояла из 14 человек, проживающих в схожих социально-экономических условиях с накопленной дозой облучения красного костного мозга менее 70 мГр за весь период своей жизни. В результате проведенного пилотного исследования у облученных лиц в отдаленном периоде после хронического низкоинтенсивного радиационного воздействия не были выявлены значимые изменения в уровне метилирования СрG-островков промоторных регионов генов CDKN1A, BCL-2, ATM относительно группы сравнения, также не были отмечены изменения в дозовых подгруппах «от 87 до 994 мГр» и «более 1000 мГр».

Ключевые слова: метилирование ДНК, СрG-островки, отдаленные эффекты облучения, хроническое облучение, метилспецифичная ПЦР

Финансирование: исследование в рамках государственного задания Федерального медико-биологического агентства России «Состояние клеточного иммунитета человека в период реализации отдаленных эффектов хронического радиационного воздействия» (27.002.20.800).

Вклад авторов: Е. А Блинова - анализ литературы, экспериментальная часть, обработка данных, написание текста статьи; В. С. Никифоров анализ литературы, экспериментальная часть, написание текста статьи; М. А. Янишевская - экспериментальная часть, редактирование текста статьи; А. В. Аклеев - общее руководство, написание текста статьи.

Соблюдение этических стандартов: исследование одобрено этическим комитетом ФГБУН УНПЦ РМ ФМБА России (протокол № 2 от 20 июля 2021 г.). Все обследованные лица подписали информированное согласие на участие в исследовании.

$\bowtie$ Для корреспонденции: Евгения Андреевна Блинова ул. Воровского, д. 68, корп. 1, г. Челябинск, 454141; blinova@urcrm.ru

Статья получена: 27.07.2021 Статья принята к печати: 29.08.2021 Опубликована онлайн: 21.09.2021

DOI: $10.47183 /$ mes.2021.028 
DNA methylation is the most common epigenetic modification, playing a vital part in regulation of cellular processes, especially in gene expression and genomic instability [1]. Of all epigenetic modifications, hypermethylation, which suppresses transcription of gene promoter regions, decreasing gene expression or causing the total shutdown of genes, is the most extensively studied [2]. However, recently there is also growing information on global hypomethylation as a factor of carcinogenesis [3].

DNA methylation status, being a rather labile system, depends largely on endogenous factors (aberrant methyltransferase activity, defects in cell's repair machinery) [4], and exogenous factors, including factors related to radiation. Thus, experimental studies involving mice showed a pronounced abnormal methylation of the tumor suppressor gene p16(INKa) promoter upon chronic low-dose radiation exposure (50 cGy). Moreover, the authors note that chronic exposure to low-dose radiation is a more powerful inducer of epigenetic effects and therefore of genomic destabilization, than the same dose acute exposure [5].

However, regardless of the actively studied human methylation status upon exposure to various adverse factors, there are currently just a few studies, showing the induction and long-term persistence of epigenetic modifications in human peripheral blood leukocytes after exposure. The existing results of a number of studies show that ionizing radiation mediates persistent DNA methylation status changes in a wide range of doses. Thus, the paper [6] reports aberrant radiation-induced methylation of genes GSTP1, CDKN2A, ARF and RASSF1A over a long period of time after exposure in the Chernobyl liquidators. Radiographers, who experienced radiation exposure in a low dose range, had genome methylation levels significantly lower compared to non-exposed individuals [7]. Hypomethylation was identified during the following study [8]: the decline in methylation of apoptosis genes (BAD, BID $\mathrm{HRK}$ ) with increasing absorbed dose was observed in blood lymphocytes of employees, who experienced occupational exposure to external radiation. Such an effect may be indicative of the differential epigenome response to low-dose and high-dose radiation exposure.

In order to present reliable findings on the DNA methylation influence on the phenotype, the changes in methylation status of gene promoter regions should be presented in the context of altered gene expression patterns. As demonstrated earlier, in the peripheral blood cells of exposed individuals after a long period of time since after exposure, the changes in homeostatic system and cellular immune response gene mRNA expression were observed. In particular, low proportion of the BCL-2 and NFKB1 gene mRNAs together with high levels of the BAX and PADI4 gene mRNAs were revealed in chronically exposed individuals over a long-term period. The decreased expression of the CDKN1A and ATM gene mRNAs was revealed in individuals, having doses to red bone marrow exceeding 1000 mGy [9].

The study was aimed to assess methylation status of $\mathrm{CpG}$ islands in BCL-2, CDKN1A and ATM gene promoters in peripheral blood cells of chronically exposed residents of the villages, located along the Techa River, over a long-term period.

\section{METHODS}

Methylation of gene promoter regions was assessed in individuals, living in the villages, located along the Techa River (Chelyabinsk region). The subjects were selected using the medical-dosimetric database developed by the department
"Database "Man" of the Urals Research Center for Radiation Medicine of the Federal Medical Biological Agency. Inclusion criteria: individuals born until 1960 inclusive; permanent residence in the territories along the Techa River in 1950-1960; availability of reconstructed absorbed dose to red bone marrow, calculated using the TRDS-2016 (Techa River Dosimetry System, version 2016) by specialists of the biophysics laboratory of the Urals Research Center for Radiation Medicine [10]. Exclusion criteria: chronic inflammatory diseases, cancer or autoimmune disorders; treatment with antibiotics, hormones or cytostatic drugs; diagnostic or therapeutic radiation exposure during a period of 6 months prior to blood sample collection; occupational exposure to chemical (genotoxic) agents.

The group of exposed individuals included 54 people with accumulated dose to red bone marrow within the range of 87-3510 mGy (the average value was $960 \pm 100$ mGy). Accumulated dose to red bone marrow in the majority of exposed people (36 individuals, 66.7\%) was within the range of 100-994 mGy. In 18 individuals, the dose exceeded 1000 mGy (33.3\%). The comparison group included 14 individuals, living in similar economic, social and household environment (rural population). However, their annual dose to red bone marrow did not exceed $1 \mathrm{mGy} / \mathrm{year}$, and the dose accumulated during the whole life was less than 70 mGy. The studied group included males and females of the following ethnic groups: Turks (mostly Tatars, Bashkirs) and Slavs, represented mostly by Russians. Characteristics of the studied groups are presented in Table 1.

DNA methylation was assessed in peripheral blood leukocytes. Samples were collected in the morning from the individuals in the fasting state using vacuum tubes with K3-EDTA. DNA was extracted from the whole blood using the GeneJET Genomic DNA Purification Kit (Thermo Scientific; USA) in accordance with the manufacturer's protocol.

The method of DNA methylation analysis was based on the specific detection of 5-methylcytosine or the products of 5-methylcytosine bisulfite conversion. Complete denaturation of genomic DNA and bisulfite treatment were performed in conditions, in which cytosine was converted stoichiometrically to uracil, but 5-methylcytosine remained nonreactive. Bisulfite conversion was performed using the EpiJET Bisulfite Conversion Kit (Thermo Scientific; USA) in accordance with the manufacturer's protocol.

Bisulfite-converted DNA was amplified with primers, specific for methylated and unmethylated DNA regions. The search for primers, required for amplification of the cell homeostatic system gene (ATM, BCL-2, CDKN1A) promoter region fragments using $P C R$, was carried out based on the available literature data. Olygonucleotides were synthesized by the DNA-Synthesis company (Russia). Characteristics of primers are presented in Table 2.

Methylation status of the gene sequences of interest was performed by the real-time methylation-specific PCR (RT-MS-PCR) using the StepOnePlus Real-Time PCR System (Applied Biosystems; USA). RT-MS-PCR was carried out with the use of the qPCRmix-HS SYBR ready-to-use reaction mix (Evrogen; Russia), containing high-fidelity Taq DNA polymerase with specific monoclonal antibodies, SYBR Green I dye, and the mixture of dNTP, $\mathrm{Mg}^{2+}$, and PCR buffer. The PCR mixture component volume and amplification conditions complied with the manufacturer's protocol and instructions.

After amplification, the target product was assessed in the PCR mixture by $2 \%$ agarose gel electrophoresis. Qualitative assessment of the presence or absence of aberrant methylation in the studied samples was performed based on the results of the described above analysis. 
Table 1. Characteristics of studied groups

\begin{tabular}{|c|c|c|c|}
\hline \multicolumn{2}{|c|}{ Parameters of the groups } & $\begin{array}{l}\text { Exposed group } \\
\qquad n=54\end{array}$ & $\begin{array}{c}\text { Comparison group } \\
n=14\end{array}$ \\
\hline \multicolumn{2}{|c|}{ Age, years, mean $\pm S D($ min-max $)$} & $73.5 \pm 0.57(65-83)$ & $74.0 \pm 0.97(68-79)$ \\
\hline \multirow{2}{*}{ Gender, $N,(\%)$} & Males & $15(27.8)$ & $4(28.6)$ \\
\hline & Females & 39 (72.2) & $10(79.0)$ \\
\hline \multirow{2}{*}{ Ethnicity, $N,(\%)$} & Slavs & $29(46.3)$ & $7(50.0)$ \\
\hline & Turks & $31(53.7)$ & $7(50.0)$ \\
\hline \multicolumn{2}{|c|}{$\begin{array}{l}\text { Average dose to red bone marrow, mGy } \\
\text { mean } \pm S D \text { (min-max) }\end{array}$} & $\begin{array}{l}960 \pm 100 \\
(87-3510)\end{array}$ & $\begin{array}{l}22 \pm 4 \\
(3-49)\end{array}$ \\
\hline
\end{tabular}

CpG Methylated Human Genomic DNA (Thermo Scientific; USA) with known methylation levels ( $\geq 98 \%$ ) was used as a methylation-positive control for all genes.

PCR with primers for methylated and unmethylated gene sequences was performed for each sample. The results of gel electrophoresis were visualized using the Gel Doc XR+ gel documentation system (BioRad; USA). The presence of the amplified products after the RT-MS-PCR with primers for methylated gene regions, detected by gel electrophoresis, indicated the presence of aberrant methylation, and the presence of the amplified products with primers for unmethylated gene regions indicated no methylation.

Statistical processing of the results was performed with the Statistica software package (StatSoft; USA). The data were compared using Fisher's exact test. The differences were considered significant when $p<0.05$.

\section{RESULTS}

The number of cases of the CpG islands' methylation in the $B C L-2, C D K N 1 A$ and ATM gene promoters in peripheral blood cells of chronically exposed individuals is presented in Table 3.

There are no significant differences in the rate of $\mathrm{CpG}$ islands' methylation in the BCL-2, CDKN1A and ATM gene promoters between the exposed individuals and the comparison group. Comparison of $\mathrm{CpG}$ islands' methylation cases in the examined individuals of the dose subgroups "87-994 mGy" and "over 1000 mGy" with the comparison group also revealed no significant differences.

\section{DISCUSSION}

Epigenetic regulation, involving DNA methylation, plays a vital part in cellular processes, maintaining proper gene expression regulation. However, aberrant methylation may result in a number of pathological conditions, genome instability and cancer [11]. It is known that ionizing radiation, being a genotoxic agent, contributes both to DNA hyper- and hypomethylation. The majority of in vitro and in vivo studies have shown that the genome epigenetic state changes have been dynamic enough early after the exposure [12]. However, there are just a few studies focused on the human DNA methylation status over a long period of time after radiation exposure. Thus, hypermethylation of CpG islands in the p16/INKA and GSTP1 gene promoters was found in blood leukocytes of the Chernobyl liquidators and the Mayak Production Association employees, dealing with reactors and radiochemical production, over a long period of time after radiation exposure [13]. The opposite results were obtained when assessing radiographers. Thus, the paper [7] reports that low-dose radiation exposure (20 mSv per year or $100 \mathrm{mSv}$ per 5 years) contributes to hypomethylation of genomic DNA in blood cells.

The results of our pilot study demonstrate no changes in methylation status of the $\mathrm{CpG}$ islands' methylation in the CDKN1A, BCL-2 and ATM gene promoter regions in chronically exposed individuals over a long period of time.

It should be noted that radiation-induced effects, associated with DNA methylation, can be affected by a number of factors: type of exposed cells, physiological characteristics of examined individuals, radiation type, dose, and time after exposure.

The results obtained are inconclusive. Better understanding of the effects of chronic low-dose radiation exposure on methylation levels requires studying the greater sample of examined individuals, and quantitative analysis, involving calculating the proportion of the gene promoter region methylation.

\section{CONCLUSIONS}

The study revealed no differences in the number of cases of CpG islands' methylation in the CDKN1A, BCL-2 and ATM

Table 2. Characteristics of olygonucleotides used for analysis

\begin{tabular}{|c|c|c|c|c|c|}
\hline Gene & Primer type & Primer sequences $\left(5^{\prime}-3^{\prime}\right)$ & $\mathrm{Tm},{ }^{\circ} \mathrm{C}$ & Amplicon length, bps & Reference \\
\hline \multirow{2}{*}{$B C L-2$} & Meth & $\begin{array}{l}\text { Forward GTTITTAGCGTTCGGTATCGG } \\
\text { Reverse AAATCTCTATCCACGAAACCGC }\end{array}$ & 60 & 192 & [8] \\
\hline & Unmeth & $\begin{array}{l}\text { Forward GGGTTTTTAGTGTTTGGTATTGG } \\
\text { Reverse AAATCTCTATCCACAAAACCACTTC }\end{array}$ & 59 & 194 & \\
\hline \multirow{2}{*}{ ATM } & Meth & $\begin{array}{l}\text { Forward GGAGTTCGAGTCGAAGGGC } \\
\text { Reverse CTACCTACTCCCGCTTCCGA }\end{array}$ & 59 & 239 & [9] \\
\hline & Unmeth & $\begin{array}{l}\text { Forward GTTTTGGAGTTTGAGTTGAAGGGT } \\
\text { Reverse AACTACCTACTCCCACTTCCAA }\end{array}$ & 56 & 246 & \\
\hline \multirow{2}{*}{ CDKN1A } & Meth & $\begin{array}{l}\text { Forward GTCGAAGTTAGTTITTGTGGAGTC } \\
\text { Reverse CGAAATCCCCTATTATCTACGC }\end{array}$ & 65 & 230 & [10] \\
\hline & Unmeth & $\begin{array}{l}\text { Forward TTGAAGTTAGTTTTTTGTGGAGTTG } \\
\text { Reverse CCAAAATCCCCTATTATCTACCAC }\end{array}$ & 66 & 230 & \\
\hline
\end{tabular}

Note: Tm — melting temperature; Meth — methylated primer; Unmeth — unmethylated primer. 
Table 3. Rate of CpG islands' methylation in BCL-2, CDKN1A and ATM gene promoters in peripheral blood cells of chronically exposed individuals

\begin{tabular}{|c|c|c|c|c|c|c|c|c|}
\hline \multirow[t]{2}{*}{ Gene $/ n^{1}$} & \multicolumn{2}{|c|}{$\begin{array}{l}\text { Comparison group } \\
<49 \mathrm{mGy}\end{array}$} & \multicolumn{2}{|c|}{$\begin{array}{l}\text { All exposed individuals with } \\
\text { the dose of } \\
87-3510 \text { mGy }\end{array}$} & \multicolumn{2}{|c|}{$\begin{array}{l}\text { Exposed individuals with } \\
\text { the dose of } \\
87-994 \mathrm{mGy}\end{array}$} & \multicolumn{2}{|c|}{$\begin{array}{l}\text { Exposed individuals with dose } \\
\qquad>1000 \mathrm{mGy}\end{array}$} \\
\hline & MP \% (n) & UMP \% (n) & MP $\%(n)$ & UMP \% (n) & $\mathrm{MP} \%(n)$ & UMP \% (n) & $\mathrm{MP} \%(n)$ & UMP \% (n) \\
\hline \multirow{3}{*}{ CDKN1A } & \multirow{3}{*}{7.1 (1) } & \multirow{3}{*}{92.9 (13) } & $0.0(0)$ & $100(53)$ & $0(0)$ & $100(36)$ & $0(0)$ & $100(17)$ \\
\hline & & & $\mathrm{F}$ & $p$ & $\mathrm{~F}$ & $p$ & $\mathrm{~F}$ & $p$ \\
\hline & & & 0.21 & $>0.05$ & 0.28 & $>0.05$ & 0.45 & $>0.05$ \\
\hline \multirow{3}{*}{$B C L-2$} & \multirow{3}{*}{18.2 (2) } & \multirow{3}{*}{$81.8(9)$} & $40.4(21)$ & 59.6 (31) & $50(17)$ & $50(17)$ & $22.2(4)$ & 77.8 (14) \\
\hline & & & $\mathrm{F}$ & $p$ & $\mathrm{~F}$ & $p$ & $\mathrm{~F}$ & $p$ \\
\hline & & & 0.3 & $>0.05$ & 0.08 & $>0.05$ & 1 & $>0.05$ \\
\hline \multirow{3}{*}{ ATM } & \multirow{3}{*}{$63.6(7)$} & \multirow{3}{*}{36.4 (4) } & $83.7(41)$ & $16.3(8)$ & $82.4(28)$ & $17.6(6)$ & 86.7 (13) & $13.3(2)$ \\
\hline & & & $\mathrm{F}$ & $p$ & $\mathrm{~F}$ & $p$ & $\mathrm{~F}$ & $p$ \\
\hline & & & 0.2 & $>0.05$ & 0.23 & $>0.05$ & $>0.05$ & 1 \\
\hline
\end{tabular}

Note: MP — number of individuals with methylated promoter; UMP — number of individuals with unmethylated promoter; F — Fisher's exact test; $p$ — significance level.

gene promoter regions between the exposed individuals and the comparison group. The results obtained are provisional. Further on it is planned to extend the panel of studied genes, and to define the proportion of methylation for each promoter region of the gene in the group of examined individuals.

\section{References}

1. Spainhour JC, Lim HS, Yi SV, Qiu P. Correlation patterns between DNA methylation and gene expression in the Cancer Genome Atlas. Cancer Inform. 2019; (18): 1-11. DOI: 10.1177/1176935119828776. PMID: 30792573. PMCID: PMC6376553.

2. Greenberg MVC, Bourchis D. The diverse roles of DNA methylation in mammalian development and disease. Nat Rev Mol Cell Biol. 2019; (20): 590-607. DOI: 10.1038/s41580-019-0159-6. PMID: 31399642.

3. Van Tongelen A, Loriot A, De Smet C. Oncogenic roles of DNA hypomethylation through the activation of cancer-germline genes. Cancer Lett. 2017; 28 (396): 130-7. DOI: 10.1016/j. canlet.2017.03.029. PMID: 28342986.

4. Edwards JR, Yarychkivska O, Boulard M, Bestor TH. DNA methylation and DNA methyltransferases. Epigenetics \& Chromatin 2017; 10 (23): 1-10. DOI: 10.1186/s13072-017-0130-8.

5. Kovalchuk O, Burke P, Besplug J, Slovack M, Filkowski J, Pogridny I. Methylation changes in muscle and liver tissues of male and female mice exposed to acute and chronic low dose X-ray irradiation. Mutat Res. 2004; 548 (1-2): 75-84. DOI: 10.1016/.j.mrmmm.2003.12.016. PMID: 15063138.

6. Kuzmina NS. Izuchenie aberrantnogo metilirovanija v lejkocitah krovi likvidatorov avarii na ChAJeS. Radiacionnaja biologija. Radiojekologija. 2014; 54 (2): 127-39. Russian.

7. Cho YH, Jang Y, Woo HD, Kim YJ, Kim SY, Christensen S, et al. LINE-1 Hypomethylation is associated with radiation-induced genomic instability in industrial radiographers. Environ Mol Mutagen. 2018; 60 (2): 174-84. DOI: 10.1002/em.22237.

\section{Литература}

1. Spainhour JC, Lim HS, Yi SV, Qiu P. Correlation patterns between DNA methylation and gene expression in the Cancer Genome Atlas. Cancer Inform. 2019; (18): 1-11.DOI: 10.1177/1176935119828776. PMID: 30792573. PMCID: PMC6376553.

2. Greenberg MVC, Bourchis D. The diverse roles of DNA methylation in mammalian development and disease. Nat Rev Mol Cell Biol. 2019; (20): 590-607. DOI: 10.1038/s41580-019-0159-6. PMID: 31399642.

3. Van Tongelen A, Loriot A, De Smet C. Oncogenic roles of DNA hypomethylation through the activation of cancer-germline genes. Cancer Lett. 2017; 28 (396): 130-7. DOI: 10.1016/j. canlet.2017.03.029. PMID: 28342986.

4. Edwards JR, Yarychkivska O, Boulard M, Bestor TH. DNA
8. Isubakova DS, Cymbal OS, Bronikovskaja EV, Litvjakov NV, Milto IV, Tahauov RM. Metilirovanie promotorov genov apoptoza $\checkmark$ limfocitah krovi rabotnikov, podvergavshihsja $\vee$ processe professional'noj dejatel'nosti dolgovremennomu vneshnemu oblucheniju. Bjulleten' jeksperimental'noj biologii i mediciny. 2021; 171 (3); 339-43. Russian.

9. Nikiforov VS, Blinova EA, Akleev AV. Vlijanie kompleksa faktorov radiacionnoj i neradiacionnoj prirody na profil' transkripcionnoj aktivnosti genov u lic, podvergshihsja hronicheskomu radiacionnomu vozdejstviju. Voprosy radiacionnoj bezopasnosti. 2019; 2 (94): 64-70. Russian.

10. Degteva MO, Napier BA, Tolstykh El, Shiskina EA, Bougrov NG, Krestinina LYu, Akleev AV. Individual dose distribution in cohort of people exposed as a result of radioactive contamination of the Techa River. Medical Radiology and Radiation Safety. 2019; 64 (3): 46-53. DOI: 10.12737/article_5cf2364cb49523.98590475.

11. Kulis M, Esteller M. DNA methylation and cancer. Adv Genet. 2010; (70): 27-56. DOI: 10.1016/B978-0-12-380866-0.60002-2. PMID: 20920744.

12. Jaenisch R. Epigenetic regulation of gene expression: how the genome integrates intrinsic and environmental signals. Nat Genet. 2003; (33): 245-54. DOI: 10.1038/ng1089. PMID: 12610534.

13. Kuzmina NS, Lapteva NSh, Rubanovich AB. Hypermethylation of gene promoters in peripheral blood leukocytes in humans long term after radiation exposure. Environ Res. 2016; (146): 10-17. DOI: 10.1016/j.envres.2015.12.008.

methylation and DNA methyltransferases. Epigenetics \& Chromatin. 2017; 10 (23): 1-10. DOI: 10.1186/s13072-017-0130-8.

5. Kovalchuk O, Burke P, Besplug J, Slovack M, Filkowski J, Pogridny I. Methylation changes in muscle and liver tissues of male and female mice exposed to acute and chronic low dose X-ray irradiation. Mutat Res. 2004; 548 (1-2): 75-84. DOI: 10.1016/j.mrfmmm.2003.12.016. PMID: 15063138.

6. Кузьмина Н. С. Изучение аберрантного метилирования В лейкоцитах крови ликвидаторов аварии на ЧАЭС. Радиационная биология. Радиоэкология. 2014; 54 (2): 127-39.

7. Cho YH, Jang Y, Woo HD, Kim YJ, Kim SY, Christensen S, et al. LINE-1 Hypomethylation is associated with radiation-induced genomic instability in industrial radiographers. Environ Mol 
Mutagen. 2018; 60 (2): 174-84. DOI: 10.1002/em.22237.

8. Исубакова Д. С., Цымбал О. С., Брониковская Е. В., Литвяков Н. В., Мильто И. В., Тахауов Р. М. Метилирование промоторов генов апоптоза в лимфоцитах крови работников, подвергавшихся в процессе профессиональной деятельности долговременному внешнему облучению. Бюллетень экспериментальной биологии и медицины. 2021; 171 (3); 339-43.

9. Никифоров В. С., Блинова Е. А., Аклеев А. В. Влияние комплекса фракторов радиационной и нерадиационной природы на профиль транскрипционной активности генов у лиц, подвергшихся хроническому радиационному воздействию. Вопросы радиационной безопасности. 2019; 2 (94): 64-70.

10. Degteva MO, Napier BA, Tolstykh El, Shiskina EA, Bougrov NG,
Krestinina LYu, Akleev AV. Individual dose distribution in cohort of people exposed as a result of radioactive contamination of the Techa River. Medical Radiology and Radiation Safety. 2019; 64 (3): 46-53. DOI: 10.12737/article_5cf2364cb49523.98590475.

11. Kulis M, Esteller M. DNA methylation and cancer. Adv Genet. 2010; (70): 27-56. DOI: 10.1016/B978-0-12-380866-0.60002-2. PMID: 20920744

12. Jaenisch R. Epigenetic regulation of gene expression: how the genome integrates intrinsic and environmental signals. Nat Genet. 2003; (33): 245-54. DOI: 10.1038/ng1089. PMID: 12610534.

13. Kuzmina NS, Lapteva NSh, Rubanovich AB. Hypermethylation of gene promoters in peripheral blood leukocytes in humans long term after radiation exposure. Environ Res. 2016; (146): 10-17. DOI: 10.1016/j.envres.2015.12.008. 